\title{
REPORT OF GROUND WATER MONITORING FOR EXPANSION OF THE GOLF COURSE, SALT LAKE City, Utah, Vitro Processing SITE

\author{
herived \\ APR $\cap 1$ iyjo \\ $\varphi>\mid 1$
}

March 1996

\section{DISCLAIMER}

This report was prepared as an account of work sponsored by an agency of the United States Covernment. Neither the United States Government nor any agency thereof, nor any of their employees, makes any warranty, express or implied, or assumes any legal liability or responsiprocess the accuracy, completeness, or usefulness of any information, apparatus, product, or process disclosed, or represents that its use would not infringe privately owned rights. Refermanufajn to any specific commercial product, process, or service by trade name, trademark, manufacturer, or otherwise does not necessarily constitute or imply its endorsement, recomand opion, or favoring by the United States Government or any agency thereof. The views and opinions of authors expressed herein do not necessarily state or reflect those of the United States Government or any agency thereof. 
INTENDED FOR PUBLIC RELEASE

This report has been reproduced from the best available copy. Available in paper copy and microfiche

Number of pages in this report: 22

DOE and DOE contractors can obtain copies of this report from:

Office of Scientific and Technical Information

P.0. Box 62

Oak Ridge, TN 37831

(615) 576-8401

This report is publicly available from:

National Technical Information Service

Department of Commerce

5285 Port Royal Road

Springfield, VA 22161

(703) 487-4650 
REPORT OF GROUND WATER MONITORING FOR EXPANSION OF THE GOLF COURSE, SALT LAKE CITY, UTAH, VITRO PROCESSING SITE

March 1996

Work performed under DOE Contract No. DE-AC04-91AL-62350

Prepared for

U.S. Department of Energy

Grand Junction Projects Office

Grand Junction, Colorado

Prepared by

Jacobs Engineering Group Inc.

Albuquerque, New Mexico 



\section{TABLE OF CONTENTS}

\section{Section}

Page

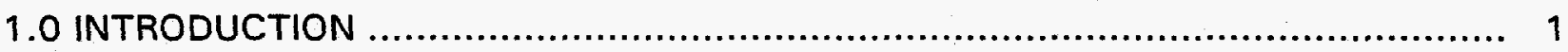

2.0 GROUND WATER ELEVATION MONITORING ACTIVITIES $\ldots \ldots \ldots \ldots \ldots \ldots \ldots \ldots \ldots \ldots \ldots \ldots$

3.0 RESULTS OF GROUND WATER ELEVATION MEASUREMENTS $\ldots \ldots \ldots \ldots \ldots \ldots \ldots \ldots \ldots, 1$

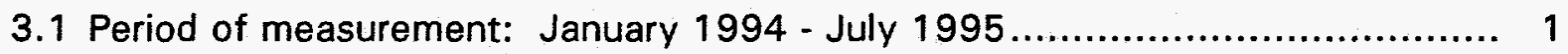

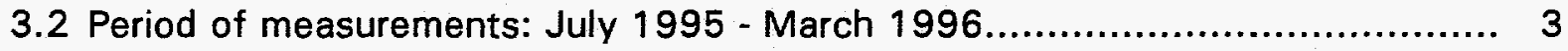

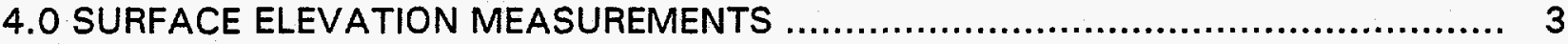

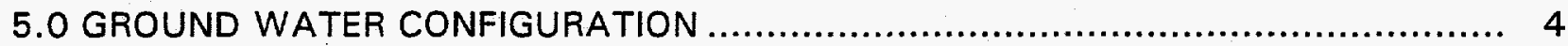

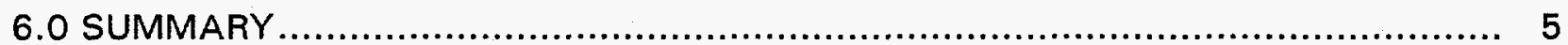

7.0 RECOMMENDATIONS FOR CONTINUED WATER LEVEL MONITORING ................ 5

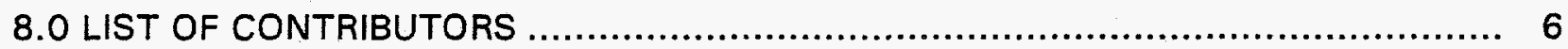

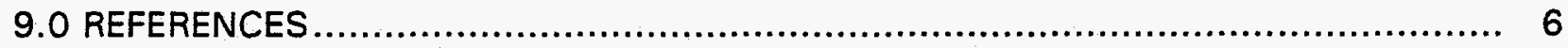




\section{LIST OF FIGURES}

Figure

Page

1 Monitor well locations, Salt Lake City, Utah, site ..................................... 7

2 Water level data, Salt Lake City, Vitro processing site (March 1994-July 1995) ................................................................. 8

3 Monthly rainfall, January 1994-July 1995, Salt Lake City airport ....................... 9

4 Ground water elevations and daily rainfall amounts, Salt Lake City, Utah, Vitro processing site

5 Ground water elevations in monitor well 135, Salt Lake City, Utah, Vitro processing site

6 Ground water elevations in monitor well 132, Salt Lake City, Utah, Vitro processing site

7 Ground water elevations in monitor well 133, Salt Lake City,

Vitro processing site

8 Ground water elevations in monitor well 130, Salt Lake City,

Vitro processing site

9 Ground water elevations in monitor well 132, August 24-September 6, 1995, Salt Lake City, Vitro processing site

10 Ground water table contours of the unconfined aquifer, Salt Lake City, Utah, site (December 1994)

11 Ground water table contours of the unconfined aquifer, Salt Lake City, Utah, site (July 1995) 


\section{LIST OF ACRONYMS}

\section{Acronym Definition}

CVWRF

Central Valley Water Reclamation Facility

UMTRA Uranium Mill Tailings Remediation Action 



\subsection{INTRODUCTION}

Ground water elevations of the shallow unconfined aquifer have been monitored at the Uranium Mill Tailings Remedial Action (UMTRA) Project, Vitro Processing site, Salt Lake City, Utah, for the purposes of characterizing ground water flow conditions and evaluating the effects of irrigation of the golf driving range. Data collected, to date, show that the water table reached its highest level for the year during March and April 1995. From May through July 1995, the water table elevations decreased in most monitor wells due to less precipitation and higher evapotranspiration. Review and evaluation of collected data suggest that irrigation of the golf driving range will have negligible effects on water levels and ground water flow patterns if rates of irrigation do not significantly exceed future rates of evapotranspiration.

\subsection{GROUND WATER ELEVATION MONITORING ACTIVITIES}

The data loggers are programmed to record hourly water level measurements. Every three to four months, these data are downloaded from the data logger and entered into the UMTRA Project database. Ground water elevation data, covering the period from March 1 to July 13 1995, were downloaded from the data logger (in operation since July 1994) in monitor well, SLC01-0131 (MW 131) on 13 July 1995. Monitor well locations are shown on Figure 1. Data loggers were installed in three additional monitor wells (MW 132, MW 133, and MW 134) at that time, and the data logger in MW 131 was moved to MW 130 . Ground water elevation data were downloaded from these four data loggers on 16 November 1995. On 4 March 1996, ground water elevation data were do wnloaded from monitor wells MW 132, MW 133, and MW 135. The data logger in monitor well 130 was inoperable at this time, and the data have not yet been retrieved from the instrument. Ground water elevation data have also been collected biweekly from five other monitor wells by the Central Valley Water Reclamation Facility (CVWRF). Daily rainfall data for the period July 1994 through July 1995 for the Salt Lake City airport were obtained from the Western Regional Climate Center in Reno, Nevada, to compare with ground water elevation data.

Surface elevations were measured at various points around the site so that elevations of surface waters and ground water could be calculated where elevation data were not previously available. These measurements included CVWRF dewatering wells and depths of excavations. Expansion of the CVWRF has required dewatering of the shallow aquifer around excavations where additional sewage treatment facilities will be installed.

\subsection{RESULTS OF GROUND WATER ELEVATION MEASUREMENTS}

\subsection{PERIOD OF MEASUREMENT: JANUARY 1994 - JULY 1995}

Ground water elevation measurements were recorded by a data logger that was installed in MW 131 located in the southeastern corner of the site. Figure 2 
shows daily values of ground water elevations for the 12 months that the data logger has been in operation. These data show that there is a difference in ground water elevations of about 2.5 feet $(\mathrm{ft})(0.8$ meter $[\mathrm{m}])$ between late summer, when the water table reaches its lowest level of the year, and late winter and spring, when the water table reaches its maximum elevation. Figure 2 also includes ground water elevation data from five other monitor wells at the site that are monitored biweekly by CVWRF. There is a gap in the data between December 1994 and April 1995 when CVWRF was unable to measure water levels. These wells show a similar pattern of ground water elevation changes as MW 131 except for MW 134 which has higher ground water elevations in the summer than in the winter and spring. Water levels in MW 134 are influenced by water levels in Mill Creek, which flows westward about $100 \mathrm{ft}(30 \mathrm{~m})$ north of MW 134.

Daily and monthly rainfall data indicate that this past winter and spring (1995) had considerably more precipitation than normal. Figure 3 shows monthly rainfall totals from January 1994 to July 1995, compared to the mean monthly rainfall for a period of record of 47 years. Total rainfall from October 1994 to June 1995 was about 50 percent higher than the mean rainfall for that period. Ground water elevations in monitor wells MW 130, MW 131, MW 132, MW 133 and $\mathrm{MW} 135$ during this period of high precipitation were $0.4 \mathrm{ft}(0.1 \mathrm{~m})$ to $2.1 \mathrm{ft}(0.64 \mathrm{~m})$ higher in May 1995 than in March 1994 when the water table was at its seasonal high. The average difference in water levels for these two dates is $1.0 \mathrm{ft}(0.3 \mathrm{~m})$.

Figure 4 shows ground water elevation data from the data logger in monitor well MW 131 plotted against daily rainfall from a station at the Salt Lake City airport. An exact correlation between rainfall amounts and increases in ground water elevations cannot be made because the airport is about 6 miles ( 10 kilometers) northwest of the site and rainfall amounts are likely to vary between the airport and the site. However, it appears that in the winter and spring the shallow aquifer is very responsive to rainfall. Increases in ground water elevations of about $0.6 \mathrm{ft}(0.2 \mathrm{~m})$ to $0.9 \mathrm{ft}(0.3 \mathrm{~m})$ over several days (for example: 12 to 14 November 1994; 15 to 17 January 1995; and 11 to 13 May 1995) correspond to rainfall events measured at the airport of about 0.9 in $(2.3 \mathrm{~cm})$ to 1.5 in $(3.8$ $\mathrm{m})$ over several days. The water table drops steadily starting in June when precipitation decreases and temperatures increase. Figure 4 shows that from June through September the water table changes very little in response to rainfall. Evapotranspiration is at its highest level during the summer months and very little precipitation is able to reach the water table. This suggests that the effects of irrigation of the golf course on ground water elevations are negligible, and that the irrigation rates do not significantly exceed evapotranspiration rates. 


\subsection{PERIOD OF MEASUREMENTS: JULY 1995 - MARCH 1996}

During this period, ground water elevation data were collected by data loggers installed in monitor wells $\mathrm{MW} 130, \mathrm{MW} \mathrm{132,MW} 133$ and MW 135. Figures 5 through 8 show bi-hourly ground water elevation data from these wells. The differences in ground water elevation patterns from these four wells indicate considerable variability of aquifer properties in the shallow unconfined aquifer across the site. Some of the shallow wells on the site are completed in channel and splay sand deposits from which considerable ground water can be extracted. Between, above, and below these sand deposits are deposits of silt and clay that limit movement of ground water (DOE, 1996). Monitor well MW 135 and CVWRF dewatering well 139 are completed in one of these channel sand deposits. Ground water elevations monitored in MW 135 show a rise of almost $5 \mathrm{ft}(1.5 \mathrm{~m})$ when the dewatering well stopped pumping in September 1995. None of the other wells being monitored at that time showed any influence of well 139 shutting down, nor when it started pumping again.

Monitor well MW 132, located adjacent to the south side of the golf driving range, shows a general decrease in ground water elevations from July to October 1995, then a rise from October 1995 to March 1996. Within these general trends are fluctuations on the order of about one quarter to one half foot over several days or a week. These changes could be due to recharge from precipitation, irrigation, or atmospheric effects. From July through September 1995, a daily pattern of ground water elevation changes of about a tenth of a foot can be seen. Figure 9 shows these changes from August 24 through September 6. During the summer, the golf course is irrigated every night for about 8 hours (Vilven, 1995). This daily rise and fall in water levels could be due either to irrigation of the golf course or to atmospheric changes. Water levels were dropping throughout the irrigation season due to decreased rainfall and high rates of evapotranspiration. After each daily rise in water level, the water table dropped more than the amount of rise. The overall decrease in water levels in MW 132 indicates that the amount of irrigation water recharging the aquifer is minimal. It is not likely that irrigation of the golf course as it exists now or of an expanded golf course would alter ground water flow and constituent migration unless considerable overwatering took place.

\subsection{SURFACE ELEVATION MEASUREMENTS}

Measurements of selected points around the site were made with a surveyor's level, tripod, and stadia rod to establish reference points for measuring the elevations of surface water bodies, ground water in wells and sumps that had not previously been measured, and water encountered at the bottom of construction excavations. Elevations of the surface waters in Mill Creek and South Vitro Ditch were measured to compare to ground water elevations in nearby monitor wells. At the time of the measurements (14 July 1995) Mill Creek was $0.76 \mathrm{ft}(0.26 \mathrm{~m})$ below the elevation of ground water in MW 134 , 
which indicates that ground water may be discharging to Mill Creek in this area. In March 1996, the water level in Mill Creek was $1.1 \mathrm{ft}(0.35 \mathrm{~m})$ above the water level in MW 134. Because the elevation of is not likely to fluctuate significantly due to the constant discharge of effluent from CVWRF, some of the water in Mill Creek may recharge the aquifer when the water table is low.

The surface elevation of water in the northern end of South Vitro Ditch was measured at $3.5 \mathrm{ft}(1.1 \mathrm{~m})$ above the elevation of ground water in MW 136. Therefore, water in South Vitro Ditch is likely recharging the aquifer in this area.

Surface elevations were measured at the two excavations at CVWRF for reference points from which depth-to-water measurements can be made. The larger excavation at location 139 (Figure 1) is being dewatered by a construction well, less than $30 \mathrm{ft}(10 \mathrm{~m})$ deep, which was installed during construction activities (about 1980 ) at CVWRF. This well is extracting ground water from the shallow aquifer at a rate of about 300 gallons per minute (1140 liters per minute). The other excavation (location 141) is being dewatered by a sump pump inside a galvanized steel casing that has been buried in coarse gravel labout $25 \mathrm{ft}(8 \mathrm{~m})$ below ground level) at the northwest corner of the excavation. Ground water extracted by the construction dewatering wells is piped into the CVWRF grit tanks. The water flows through the process system and is eventually discharged into Mill Creek (Figure 10).

An inactive dewatering well (location 140) is located next to Mill Creek. The elevation of the top of casing in this well and the depth to water were measured. The elevation of ground water in this well is about $4 \mathrm{ft}(1.2 \mathrm{~m})$ lower than the surface elevation of water in Mill Creek. The reason for the low water table in this area could be either the extensive dewatering taking place for the current construction activities or additional dewatering from drains and sump pumps installed below CVWRF.

\subsection{GROUND WATER CONFIGURATION}

Figure 10 shows ground water table contours from December 1994, prior to the start of dewatering for the current construction activities. This figure shows that ground water flow in the shallow unconfined aquifer beneath the site is predominantly to the northwest. Figure 11 shows ground water table contours for the unconfined aquifer in July 1995. The most noticeable features on this map are the closed depressions in the water table around the dewatering wells at CVWRF and around the lift station at the railroad and Interstate 15 overpass on South 3300 Street underpass. Ground water extracted by the lift station is discharged into South Vitro Ditch, which discharges into Mill Creek. The 4230-ft and $4240-\mathrm{ft}$ contour lines on Figure 10 indicate that, aside from water diverted to the surface by the various dewatering wells on and near the site, ground water flows generally to the northwest.

Ground water elevations in MW 135 indicate that there is a depression in the water table in this area, however, the cause of this depression has not been fully determined. Water 
levels measured in this well since 1992 are about $5 \mathrm{ft}(1.5 \mathrm{~m})$ lower than water levels measured in this area in 1982 and 1983 (DOE, 1984). The low levels of ground water in MW 135 cannot be fully attributed to the recent dewatering activities because CVWRF dewatering started in January 1995, and water levels have been low since at least 1992. This suggests that there are other features that are draining the aquifer in this area. Possibilities for such drainage are sump pumps below the sewage treatment facility, or flow of ground water from the site along the gravel fill around pipelines that connect to other CVWRF and sewage treatment facilities, or flow into the sewer mains that discharge into CVWRF or other such facilities.

\subsection{SUMMARY}

Water level measurements from monitor wells, dewatering wells, surface water bodies, and excavations give a clearer picture of the water table configuration at the Vitro Processing Site than was previously available from measurements made only in monitor wells. These measurements show that a considerable amount of ground water is being extracted or drained from the shallow aquifer by dewatering wells. The ground water flow pattern induced by this extraction appears to have a significant impact on the movement of site-related constituents in the shallow aquifer. Movement of contaminated ground water off- site is diminished due to CVWRF ground water extraction, and the amount of site-related constituents in the aquifer will be reduced because of the increased ground water flow onto the site, flushing site waters toward the CVWRF extraction wells.

A comparison of ground water elevations and rainfall events shows that in the winter and spring the aquifer is very responsive to rainfall events. However, during the summer, when evapotranspiration is high, rainfall has negligible impact on ground water levels. It is not likely that irrigation of the present golf driving range on the site or an expansion to a nine-hole golf course will have any significant impact on ground water levels or constituent migration, assuming irrigation application rates are comparable to those currently being used.

\subsection{RECOMMENDATIONS FOR CONTINUED WATER LEVEL MONITORING}

Data collected from the three data loggers now functioning in three monitor wells at the site will provide additional information about ground water flow patterns and the impact of irrigation of the golf driving range on water levels and ground water flow. It is recommended that monitoring of ground water levels using the data loggers and other water level monitoring points continue at least until December 1996. This will allow for ground water level measurements from the more extensive monitoring network through the summer irrigation period and into the period of higher rainfall with higher water levels.

Also, water levels can be monitored as the CVWRF dewatering wells are shut down when construction activities are completed in 1996. Water levels in MW 132, adjacent to the golf driving range, should be recorded and compared to irrigation records and to atmospheric data to determine if the daily patterns in water levels from this well during the 


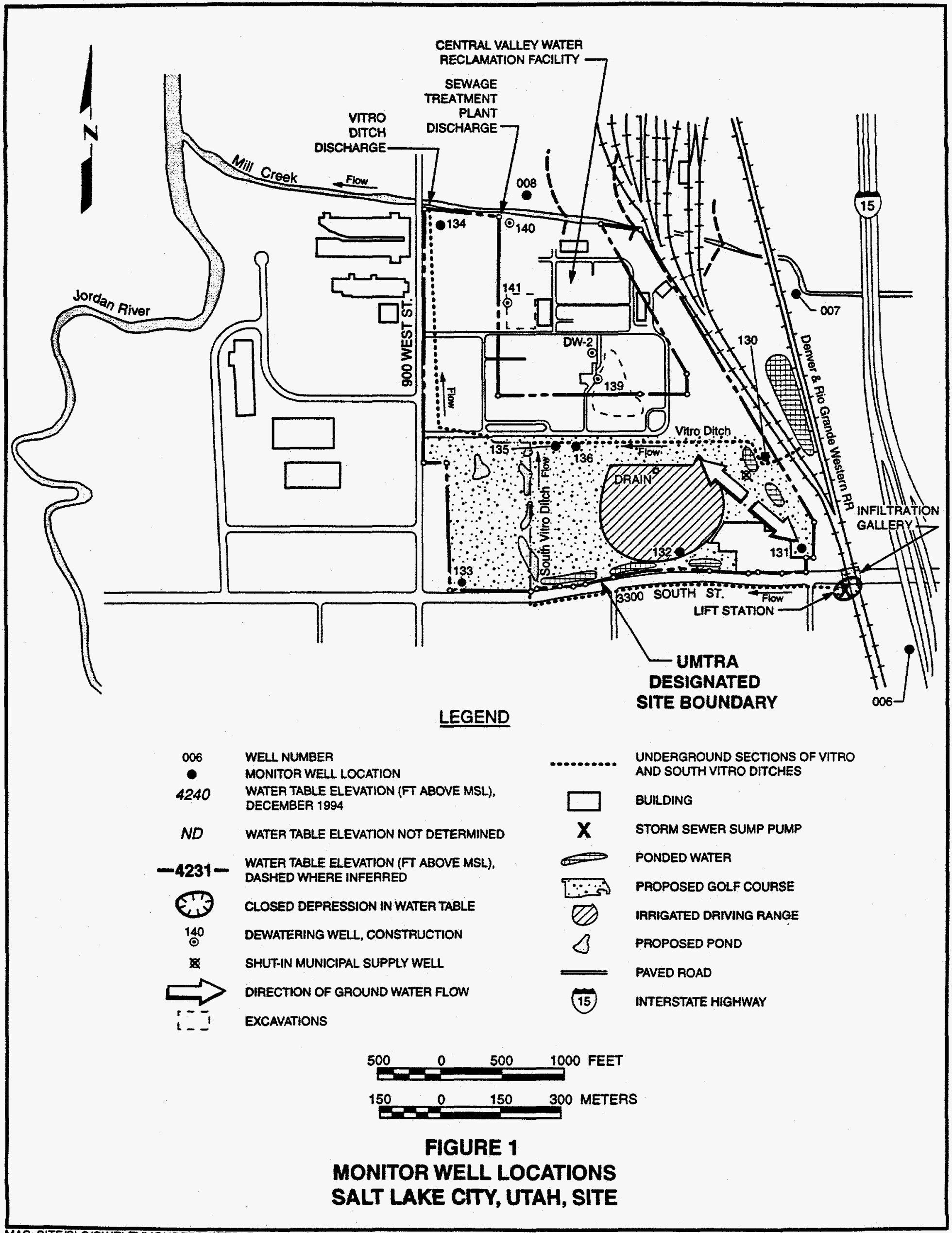




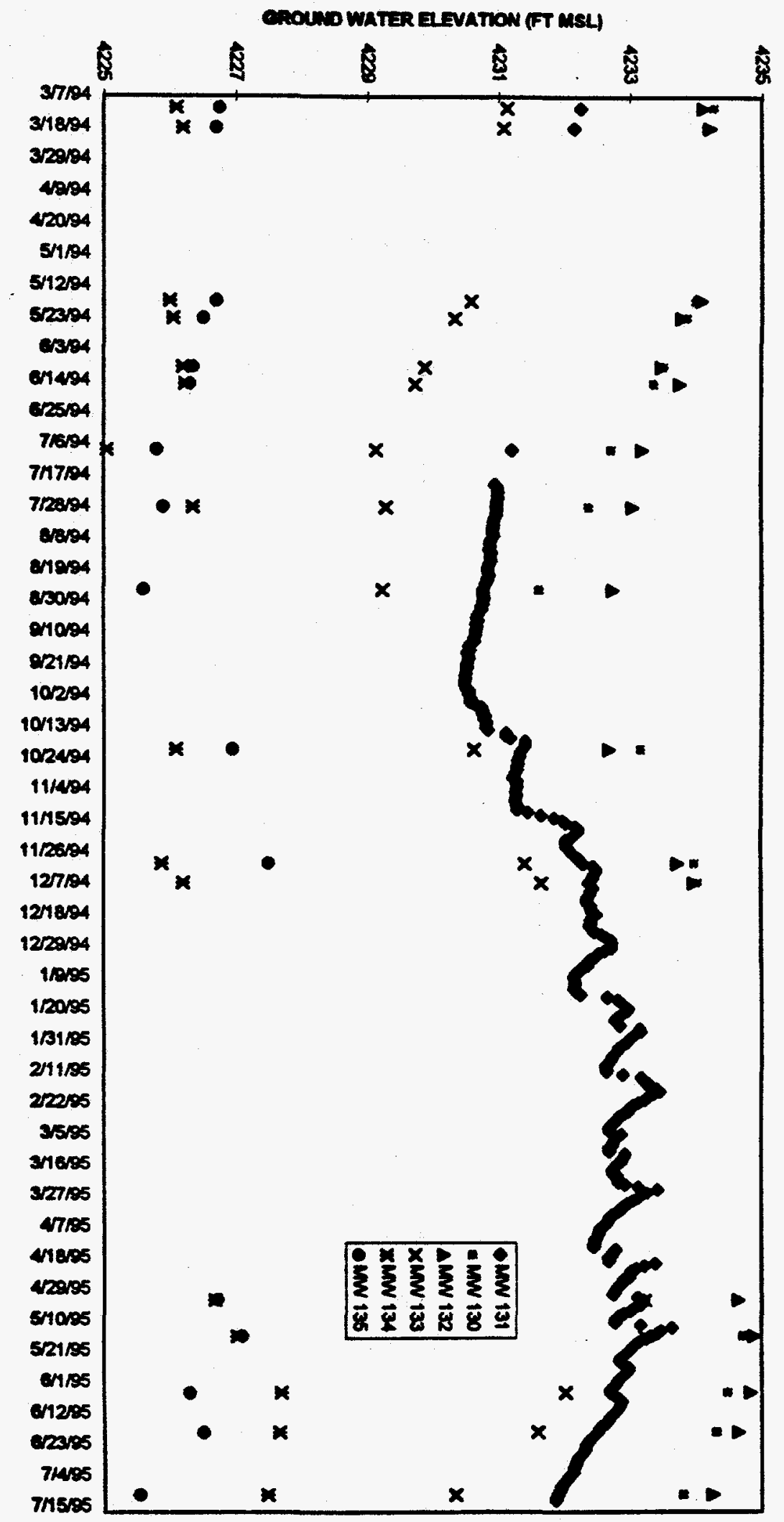

FIGURE 2

WATER LEVEL DATA, SALT LAKE CITY, VITRO PROCESSING SITE (MARCH 1994 - JULY 1995) 


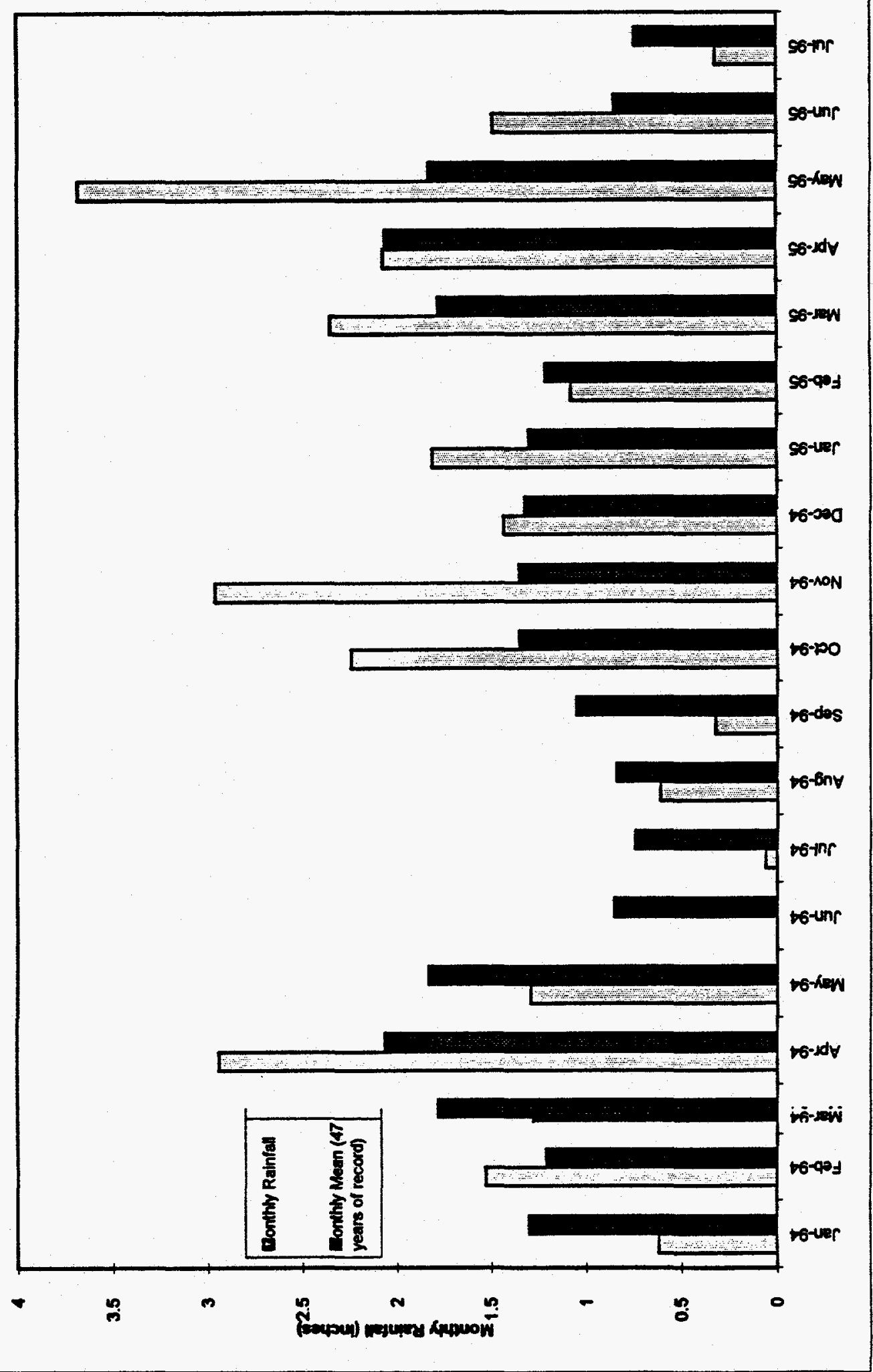

FIGURE 3

MONTLY RAINFALL, JANUARY 1994 - JULY 1994

SALT LAKE CITY AIRPORT 


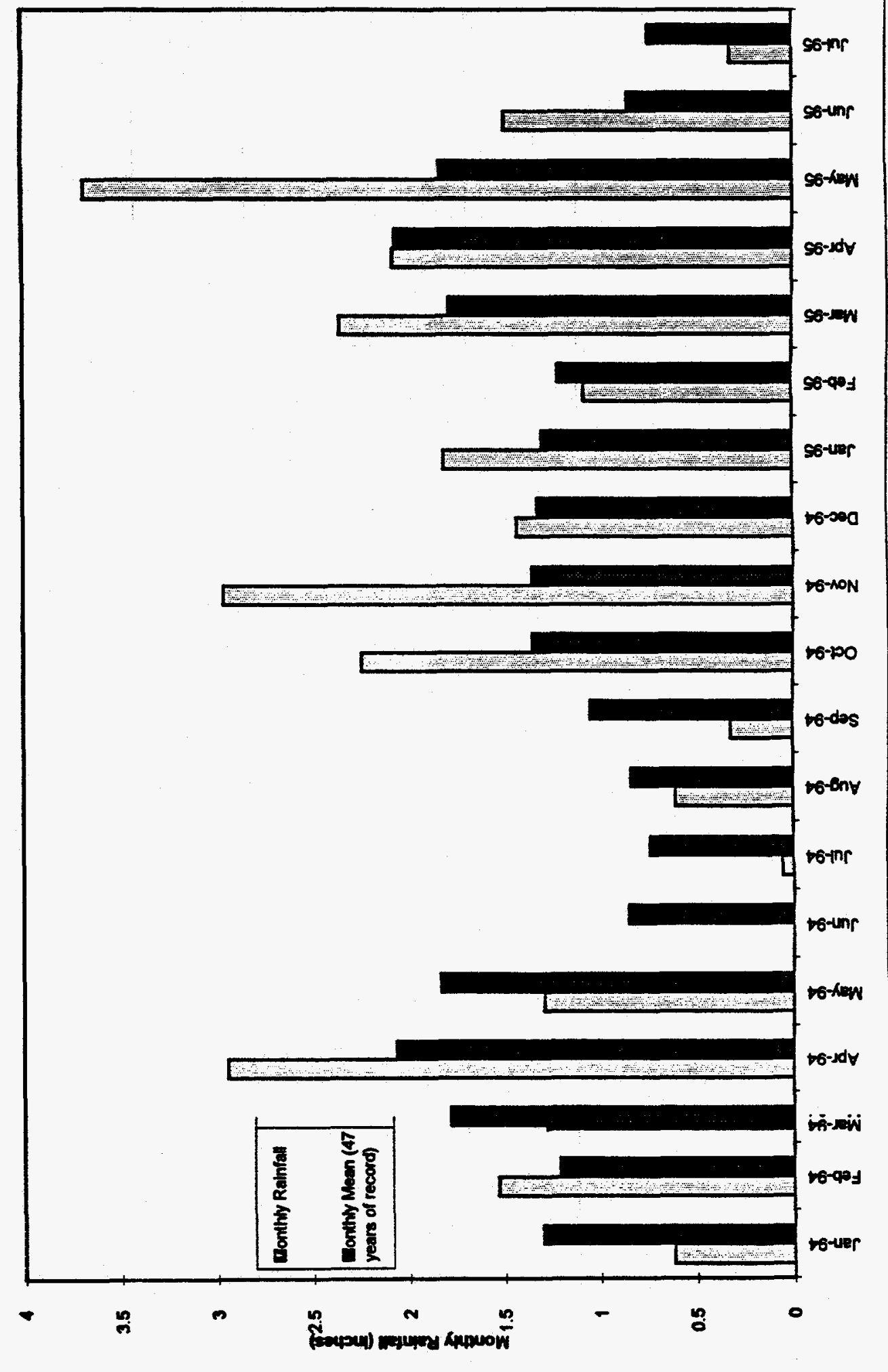

FIGURE 3

MONTHLY RAINFALL, JANUARY 1994 - JULY 1994

SALT LAKE CITY AIRPORT 

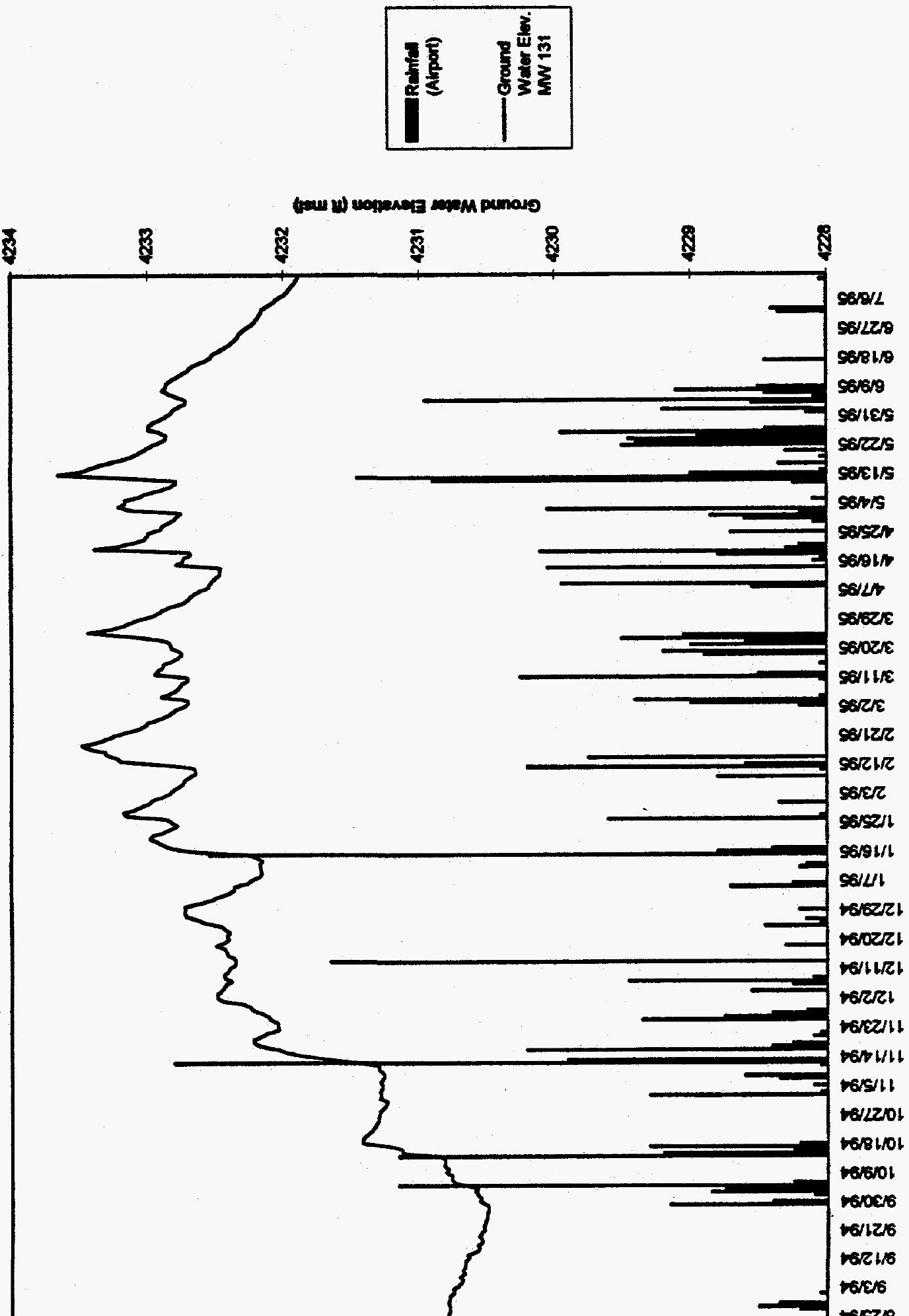


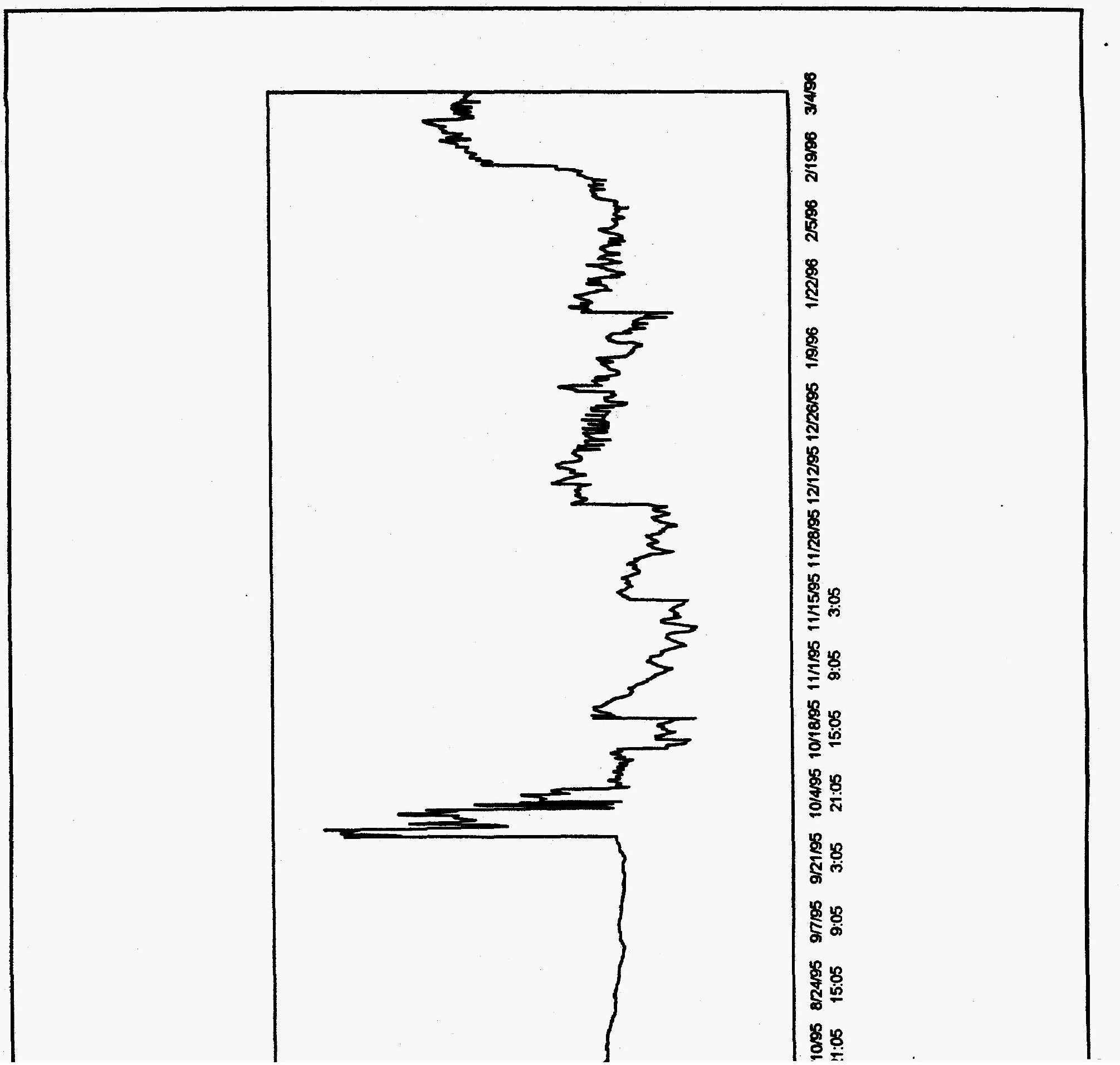




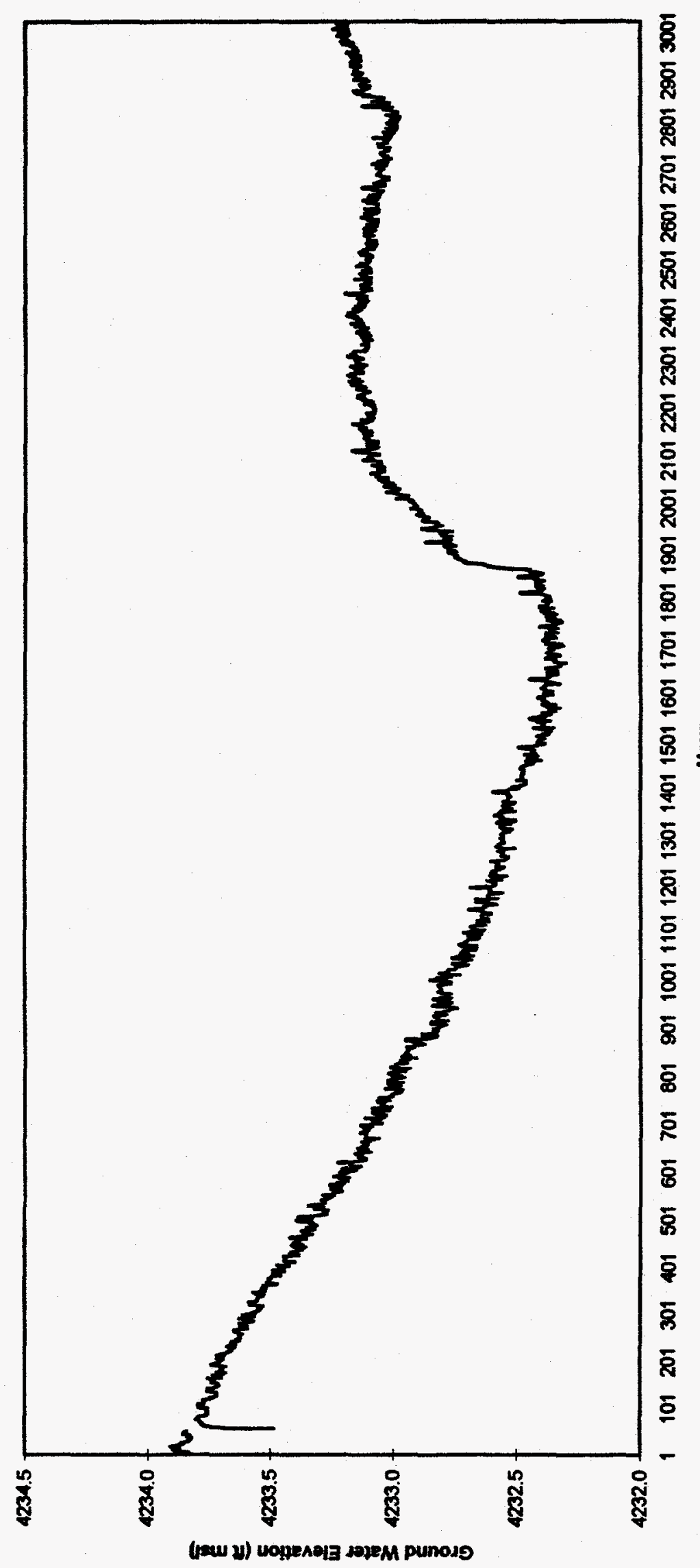

FIGURE 8

GROUND WATER ELEVATIONS IN MONITOR WELL 130

SALT LAKE CITY, UTAH, VITRO PROCESSING SITE 


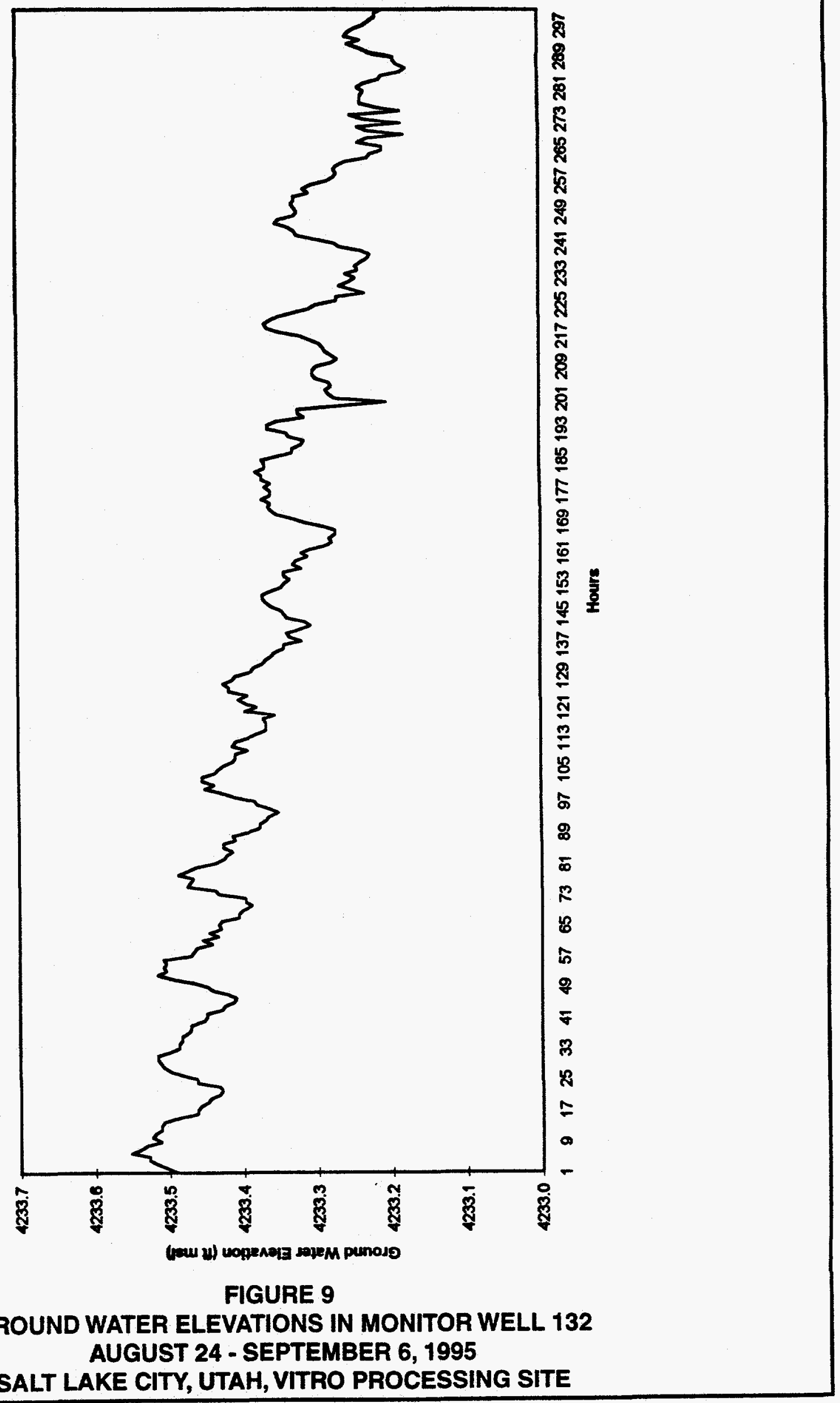




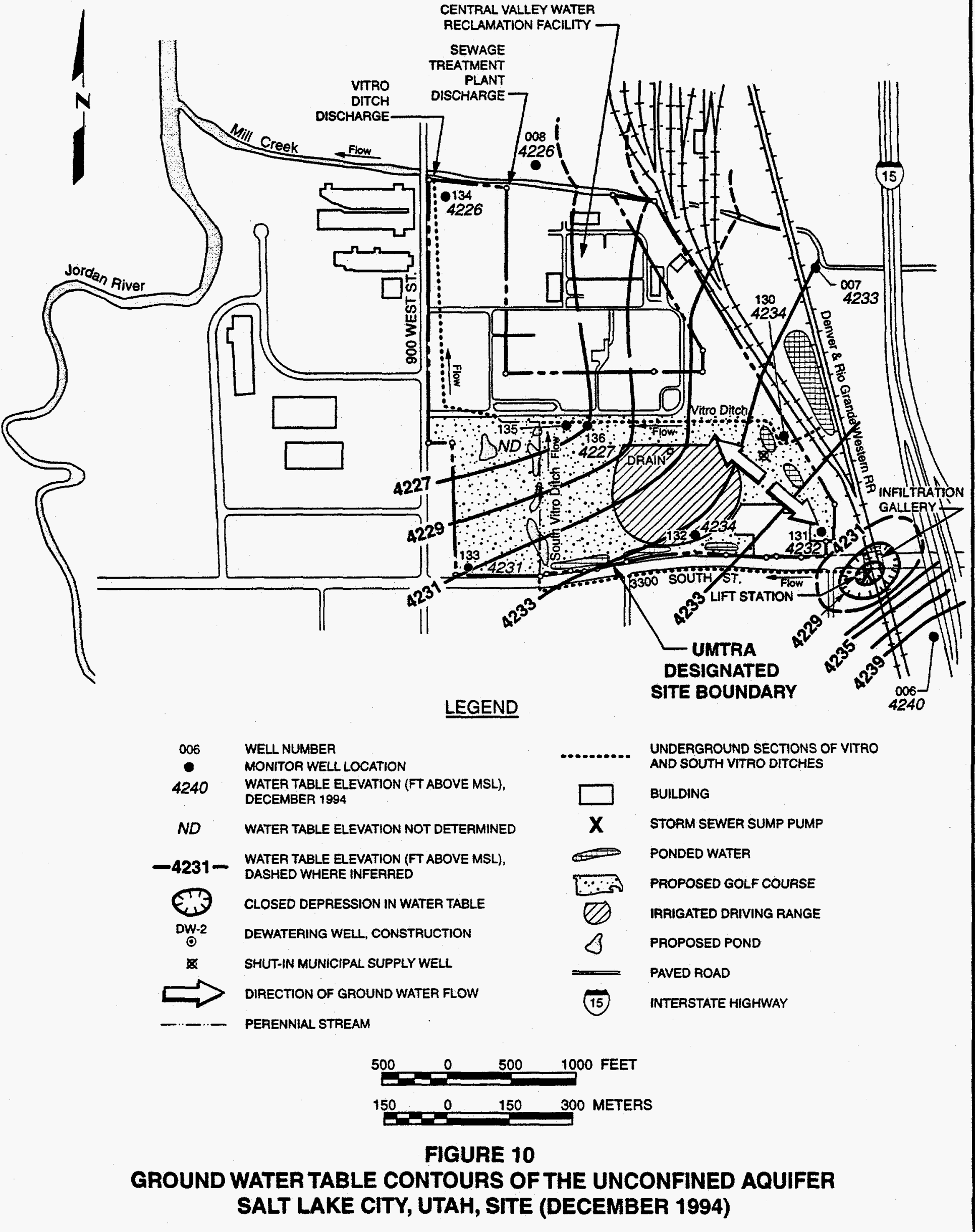




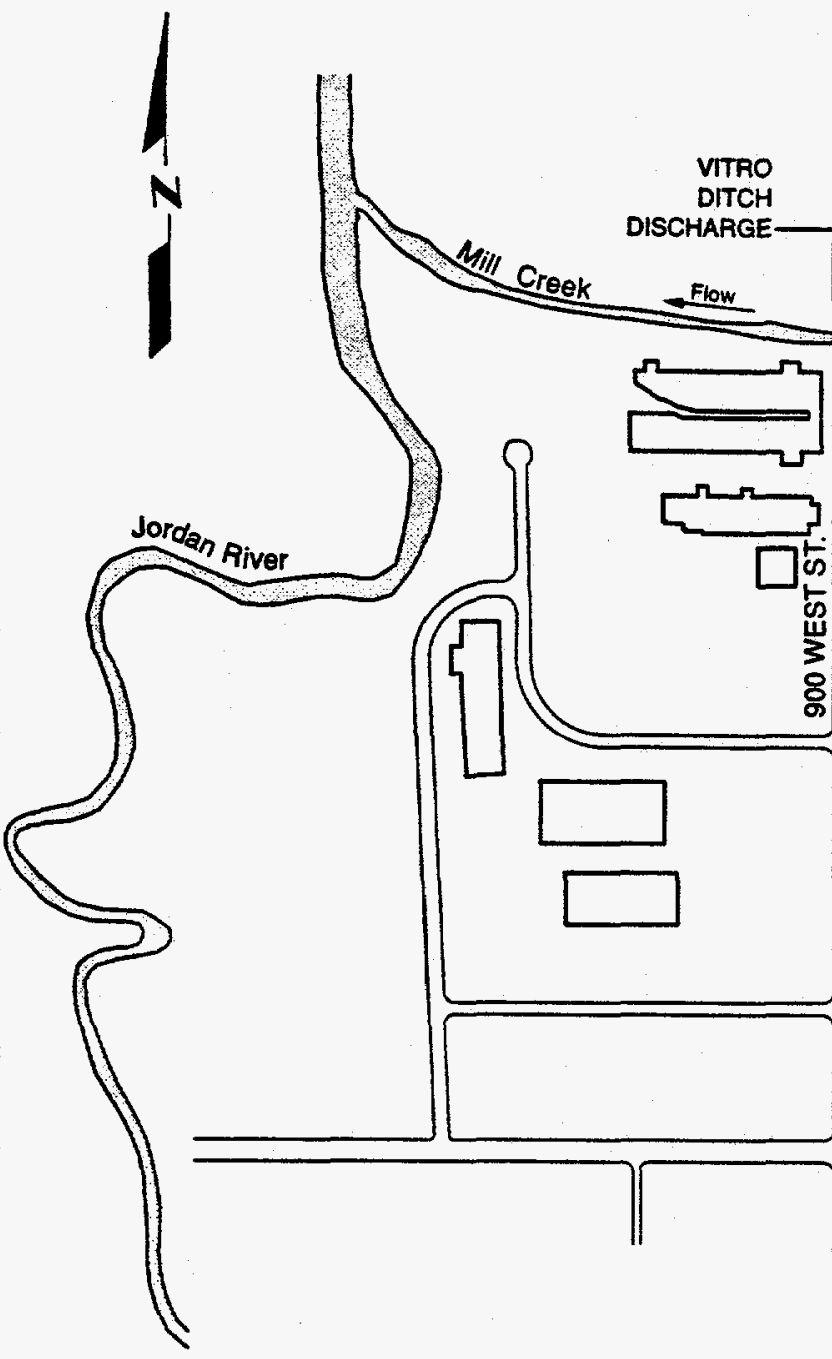

CENTRAL VALLEY WATER

RECLAMATION FACILITY

SEWAGE

TREATMENT

PLANT

DISCHARGE -
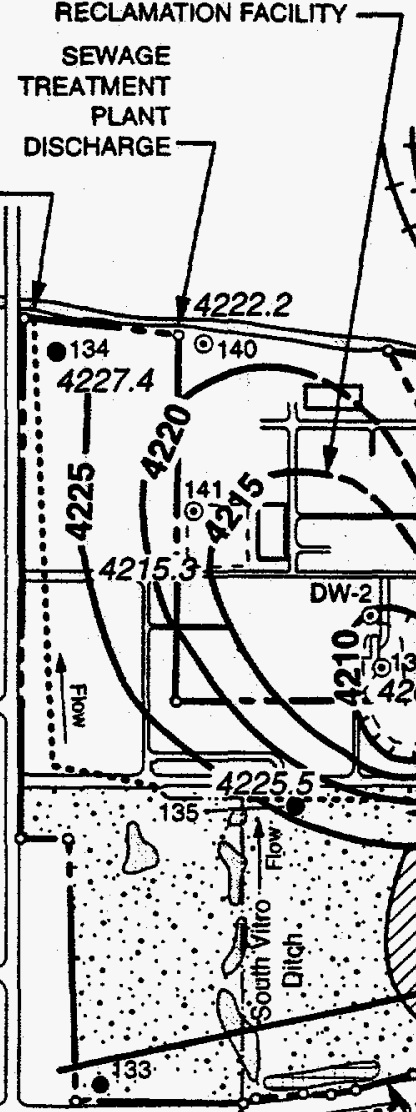

4230.3

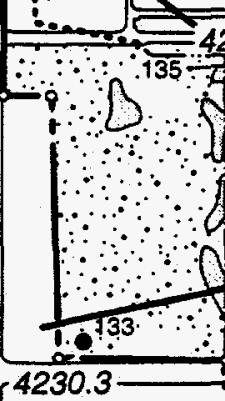

LEGEND

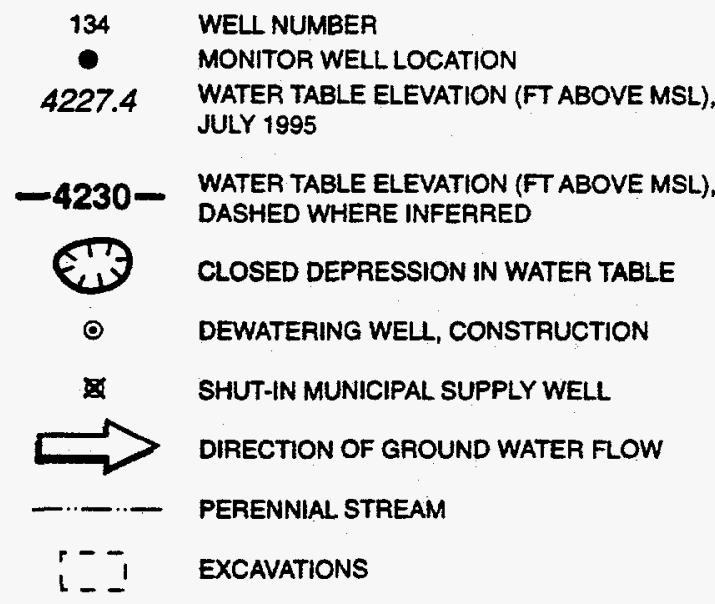
AND SOUTH VITRO DITCHES

BUILDING

PONDED WATER

$\because \because{ }^{\prime}$ PROPOSED GOLF COURSE

QD IRRIGATED DRIVING RANGE

1 PROPOSED POND

$=$ PAVED ROAD

(15) INTERSTATE HIGHWAY

NOTE: CONTOUR INTERVAL 5 FT.

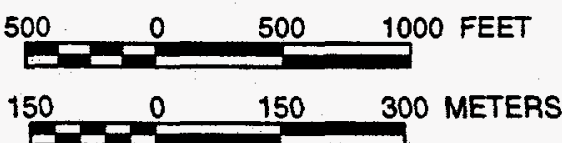

FIGURE 11

GROUND WATER TABLE CONTOURS OF THE UNCONFINED AQUIFER SALT LAKE CITY, UTAH, SITE (JULY 1995) 